\title{
TRUST, DIVERSITY AND SEGREGATION
}

\author{
Seminar Series 2010
}

When:

Wednesday $17^{\text {th }}$ November 2010, 4pm - 6pm

Where:

Cosmopolitan Civil Societies Research Centre, UTS City Campus

Level 3, Mary Ann House, 645 Harris Street, Sydney

(a short walk from Central Railway Station)

\section{Programme}

CHAIR - Professor Jenny Onyx, UTS, Coordinating CoDirector CCS

TRUST, DIVERSITY, AND SEGREGATION IN THE UNITED STATES AND UNITED KINGDOM

40 minutes

Professor Ric Uslaner, Department of Government and Politics, University of Maryland

Professor Ric Uslaner, Professor of Government and Politics at the University of Maryland is the 2010 Fulbright ANU Distinguished Chair. Professor Uslaner is spending four months at ANU from September 2010. Ric will be researching issues of trust and ethnicity in populations. Professor Uslaner is visiting The Cosmopolitan Civil Societies Research Centre, UTS on 17 November to present a lecture on Trust, Diversity and Segregation in the United States and United Kingdom as part of the 2010 CCS Seminar Series.

Generalized trust is a value that leads to many positive outcomes for a society-greater tolerance of minorities, greater levels of volunteering and giving to charity, better functioning government, less corruption, more open markets, and greater economic growth."

Some political leaders and academics have argued that trust is lower in a diverse society-and there are also fewer acts of altruism that benefit people who are different from yourself. People feel uncomfortable in trusting people who are different from themselves. However, this argument confuses diversity with residential segregation. When people live apart from those of other backgrounds, they won't develop the sorts of close ties that can lead to greater trust in people who are different from themselves. Even if they live in integrated communities, they must have frequent and close interactions with people of different backgrounds for trust to flourish.

TRUST, DIVERSITY, AND SEGREGATION: A LOCAL PERSPECTIVE

20 minutes

Violet Roumeliotis, Manager, Canterbury Bankstown Migrant Resource Centre

Violet Roumeliotis will be addressing the topic of Trust, Diversity and Segregation from a local perspective, informed by her work in a highly diverse region of Sydney as Manager of the Canterbury Bankstown Migrant Resource Centre. Violet is a member of the CCS Advisory Board.

\section{DISCUSSANT}

Professor Jock Collins, UTS:CCS

Jock Collins is Professor of Economics at the University Technology Sydney (UTS) where his research interests centre on an interdisciplinary study of immigration and cultural diversity in the economy and society, a field that he has published in since 1974.

His recent research has been on Australian immigration, ethnic crime, immigrant entrepreneurship, ethnic precincts and tourism and the social use of ethnic heritage and the built environment.

Presentations will be followed by wider discussion led by Professor Jock Collins. Refreshments will be provided.

\section{REGISTRATION}

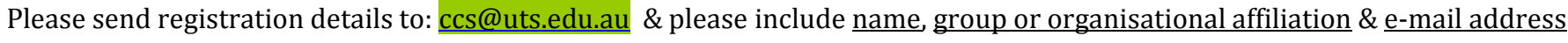

